\title{
Analisis Pertumbuhan Tanaman Tebu (Saccharum officinarum L.) Akibat Aplikasi Vermikompos dan Plant Growth Promoting Rhizobacteria (PGPR)
}

\section{(Sugarcane [Saccharum officinarum L.] Growth Analysis as Affected by Vermicompost and Plant Growth Promoting Rhizobacteria [PGPR])}

\author{
Nadya Muliandari ${ }^{1 *}$, Sudiarso ${ }^{2}$, Titin Sumarni ${ }^{2}$ \\ ${ }^{1}$ Pascasarjana Program Studi Agronomi Fakultas Pertanian Universitas Brawijaya Jl. Veteran, \\ Malang, Jawa Timur, Telp.: (0341) 551611. 65145, ${ }^{2}$ Jurusan Budidaya Pertanian Fakultas \\ Pertanian Universitas Brawijaya Jl. Veteran, Malang, Jawa Timur, Telp.: (0341) 551611. 65145 \\ E-mail: muliandari.nadya@gmail.com
}

\section{ARTICLE INFO}

Article history

Submitted: February 18, 2021

Accepted: September 10, 2021

Published: October 18, 2021

Keywords:

cultivation technique,

organic matter,

soil fertility

\begin{abstract}
Sugarcane (Saccharum officinarum L.) play an important role for sugar consumption in Indonesia. Problem found with sugar industry in Indonesia is the low productivity of sugarcane because of cultivation techniques caused by low soil fertility. This research aimed to determine effect of Plant Growth Promoting Rhizobacteria (PGPR) and vermicompost in increasing the growth of sugarcane. The research method used Randomized Block Design (RBD) consisted of 2 factors with a combination of 6 treatments. The first factor was $A_{1}=$ without PGPR $A_{2}=P G P R\left(10 \mathrm{ml} . \mathrm{L}^{-1}\right)$ and the second factor was $P_{1}=$ 3.5 t.ha $\mathrm{h}^{-1}$ (50\% vermicompost recommended fertilizer), $P_{2}=7 . t \mathrm{ha}^{-1}$ (100\% vermicompost recommended fertilizer) and $P_{3}=10.5$ t.ha ${ }^{-1}$ (150\% vermicompost recommended fertilizer). Variables of this observation are plant height, number of tillers, number of stems, number of internodes, stem diameter, brix value and the yield of sugarcane. At the age 7 months after planting, the treatment of PGPR application at a vermicompost dose of 7 t.ha- $\left(78.46\right.$ t.hal $\mathrm{h}^{-1}$ ) was able to reduce the need for a vermicompost dose which was shown by a higher yield value compared to without PGPR application with vermicompost 3.5 t.hat and vermicompost dose of 7 t.ha $\mathrm{h}^{-1}$. A higher stem weight obtained in the PGPR treatment when compared to the treatment without PGPR. At a vermicompost 7 t.ha ${ }^{-1}$ and a vermicompost 10.5 t.hat $\mathrm{h}^{-1}$ showed a higher stem weight compared to vermicompost 3.5 t. $\mathrm{ha}^{-1}$.
\end{abstract}

Copyright (C) 2021 Author(s). This work is licensed under a Creative Commons AttributionShareAlike 4.0 International License.

\section{PENDAHULUAN}

Tanaman tebu (Saccharum officinarum L.) memiliki peran penting dalam pemenuhan konsumsi gula di Indonesia. Tebu berperan dalam keberlangsungan industri gula sebagai pemenuh kebutuhan gula nasional. Salah satu permasalahan perindustrian gula di Indonesia adalah masih rendahnya produktivitas tebu akibat dari teknis budidaya yang kurang optimal (Tando, 2017). Selain itu, hasil tebu tersebut yang rendah juga antara lain dikarenakan oleh rendahnya kesuburan 
tanah pada lahan tanaman tebu. Berbagai hasil penelitian telah menunjukkan lahan pertanian di Indonesia telah mengalami degradasi lahan. Hampir $73 \%$ lahan pertanian yang ada di Indonesia memiliki nilai bahan organik tanah kurang dari $2 \%$ (Nisaa et al., 2016).

Berbagai sumber bahan organik dapat berasal dari limbah organik yang dikomposkan. Teknik pengomposan limbah organik dengan bantuan cacing biasa dikenal dengan vermikompos. Mineralisasi unsur hara tanah seperti N, P dan K dapat membantu dekomposisi bahan organik tanah dengan bantuan enzim tanah. Peningkatan aktivitas enzim tanah merupakan dampak dari bahan organik yang tinggi maupun pertumbuhan mikroba yang tinggi sehingga menstimulasi aktivitas mikroorganisme sehingga meningkatkan ketersediaan dari unsur hara tanah (Zhang et al., 2019). Penambahan bakteri seperti yang terkandung didalam plant growth promoting rhizobacteria (PGPR) berperan didalam proses dekomposisi bahan organik dengan mengkolonisasi akar tanaman dengan cara masuk kedalam akar tanaman khususnya pada bagian rhizosfer. Mekanisme PGPR dalam fiksasi nitrogen yang dilakukan oleh genus bakteri Azotobacter spp. yaitu dengan memfiksasi nitrogen dari udara yang selanjutnya dilepaskan dalam tanah dan diserap oleh akar tanaman. Bakteri ini juga berperan sebagai penambat $\mathrm{N}$ di dalam tanah (Setiawati et al., 2018). PGPR berpengaruh terhadap pertumbuhan tanaman diantaranya yaitu meningkatkan nitrogen di dalam tanah, melarutkan fosfat, melarutkan kalium yang tidak larut dalam tanah, serta memproduksi fitohormon untuk mendukung pertumbuhan tanaman (Bhattacharyya et al., 2020).

Pada penelitian sebelumnya mengenai efektivitas sumber fosfat dan kalium dengan kompos cacing tanah dengan bakteri diazotrofik (OM) dan diterapkan pada 50, 100 dan $150 \%$ berpengaruh positif terhadap tinggi, hasil, dan karakteristik tanaman tebu (Stamford et al., 2015) serta pengaruh pemberian PGPR berupa bakteri Pseudomonas fluorescens dan Bacillus subtilis dengan populasi sebesar 109 cfu.ml ${ }^{-1}$ mampu mempercepat pertumbuhan bibit tebu bud chip varietas PS 882 (Sulistyoningtyas et al., 2017). Penelitian ini merupakan penelitian lanjutan untuk mengkaji pengaruh vermikompos dan efektivitas PGPR pada lahan tanaman tebu. Tujuan dari penelitian ini yaitu untuk dapat mengetahui pengaruh PGPR dan vermikompos dalam meningkatkan pertumbuhan tanaman tebu.

\section{METODE PENELITIAN}

Penelitian ini dilakukan pada bulan Oktober 2019 hingga Juni 2020 yang bertempat di Puslit Sukosari PTPN XI, Kabupaten Lumajang, Jawa Timur, Indonesia. Lokasi berada pada ketinggian \pm $329 \mathrm{~m} \mathrm{dpl}$, suhu udara sekitar $25-27^{\circ} \mathrm{C}$, dan curah hujan $\pm 1.860 \mathrm{~mm}$.tahun ${ }^{-1}$. Bahan yang digunakan dalam penelitian ini yaitu bibit single bud planting (SBP) varietas Bululawang (BL), pupuk ZA, SP36 dan $\mathrm{KCl}$, pupuk vermikompos serta PGPR. PGPR yang digunakan menggunakan Pupuk Hayati Cair "R1M" yang terdiri dari bakteri Azospirillum sp., Azotobacter sp., Pseudomonas sp., Rhizobium sp., Bacillus sp., dan Sacharomyces sp.

Metode yang digunakan dalam penelitan ini yaitu rancangan acak kelompok (RAK) yang terdiri atas 2 faktor dengan kombinasi enam perlakuan. Masing-masing perlakuan dilakukan pengulangan sebanyak empat kali. Faktor pertama pada penelitian ini yaitu PGPR dengan dua taraf, yaitu: $\mathrm{A}_{1}=$ Tanpa PGPR dan $\mathrm{A}_{2}=$ PGPR $\left(10 \mathrm{ml} . \mathrm{L}^{-1}\right.$ atau $100 \%$ konsentrasi PGPR). Faktor kedua adalah pupuk vermikompos dengan tiga taraf, yaitu: $\mathrm{P}_{1}=3,5$ t.ha $^{-1}$ (50\% pupuk anjuran vermikompos), $\mathrm{P}_{2}=7$ t.ha- ${ }^{-1}$ (100\% pupuk anjuran vermikompos), dan $\mathrm{P}_{3}=10,5$ t.ha ${ }^{-1}$ (150\% pupuk anjuran vermikompos). Persiapan lahan dimulai dengan mengukur lahan yang digunakan yaitu 
seluas 0,22 ha dengan luas petak pengamatan sebesar $44 \mathrm{~m}^{2}$. Masing-masing petak percobaan terdiri atas 5 juring dengan pusat ke pusat (PKP) 1,1 meter dengan tinggi $30 \mathrm{~cm}$. Jumlah juring yang digunakan pada lahan penelitian yaitu 135 juring. Lebar got 0,5 meter dengan jalan $0,5 \mathrm{~m}$. Vermikompos diaplikasikan dengan cara ditebarkan diatas tanah kemudian dibenamkan ke dalam tanah. Dosis yang digunakan yaitu untuk perlakuan dosis vermikompos 3,5 t.ha-1 ${ }^{-1}$, per juringnya dibutuhkan sebanyak 3,08 $\mathrm{kg}$ dan per petak sebanyak 15,4 kg. Dosis vermikompos $7 \mathrm{t}^{\mathrm{h} \mathrm{ha}^{-1}}$, per juringnya dibutuhkan sebanyak $6,16 \mathrm{~kg}$ dan per petak sebanyak $30,8 \mathrm{~kg}$. Serta dosis vermikompos 10,5 t.ha $^{-1}$, per juringnya dibutuhkan sebanyak $9,24 \mathrm{~kg}$ dan per petak sebanyak $46,2 \mathrm{~kg}$. Sebelum bibit ditanam, lahan digenangi agar proses penanaman lebih mudah. Umur bibit single bud planting (SBP) yang digunakan yaitu telah berumur 3 bulan. Aplikasi PGPR dilakukan sebanyak 2 kali yaitu pada 1 dan 3 minggu setelah tanam dengan konsentrasi rekomendasi $10 \mathrm{ml}$ yang dilarutkan di dalam satu liter air. Dosis PGPR (PGPR + air) per petak sebanyak 2,2 liter dengan dosis PGPR (PGPR + air) per tanaman sebanyak 22,22 ml per tanaman. Aplikasi PGPR yaitu dengan menggunakan sprayer yang diarahkan kepada perakaran tanaman. Pengairan pada lahan tanaman tebu dilakukan dengan cara mengaliri air (dileb) setinggi $20 \mathrm{~cm}$ mengelilingi juringan. Pengairan dilakukan sebanyak 4 kali yaitu sehari sebelum penanaman, 7 HST, 14 HST, dan 21 HST. Penyiangan dilakukan apabila lahan sudah tumbuh gulma dan dilakukan secara manual dan mekanik menggunakan sabit atau cangkul. Penyiangan dilakukan tergantung kondisi gulma pada lahan. Pembumbunan pada lahan tebu dilakukan 2 kali yaitu pada umur $1-1,5$ bulan dan umur 2,5-3 bulan setelah tanam.

Variabel pengamatan yang diamati pada penelitian ini mencakup komponen pertumbuhan yang diantaranya tinggi tanaman, jumlah anakan, jumlah batang, jumlah ruas, diameter batang, nilai brix dan taksasi hasil tanaman tebu. Pengamatan tinggi tanaman dengan cara mengukur batang tanaman dari permukaan tanah hingga sendi daun pertama (segitiga daun teratas) dengan menggunakan paralon yang telah diberi pembatas. Pengamatan jumlah anakan dengan cara menghitung anakan dalam satu rumpun tanaman tebu. Pengamatan jumlah ruas dengan cara menghitung jumlah ruas yang ada pada batang tiap rumpun. Pengamatan diameter batang dengan menggunakan alat jangka sorong dan dihitung pada bagian atas, tengah dan bawah batang dan dihitung rata-ratanya. Pengamatan nilai brix dengan menggunakan alat hand refraktometer (dalam ${ }^{\circ}$ Brix). Pengambilan sampel pada tiap batang diambil pada batang bagian atas, tengah dan bawah yang selanjutnya dirata-rata. Larutan gula tebu ditetesi pada alat kemudian muncul nilai brix tanaman tebu. Pengamatan nilai taksasi hasil dengan menggunakan nilai hasil tebu per juring pada setiap perlakuan. Data hasil pengamatan selanjutnya dianalisis menggunakan analisis ragam (Uji F) dengan taraf 5\% dan jika terdapat pengaruh nyata dari perlakuan, dilanjutkan dengan uji beda nyata jujur (BNJ) dengan taraf 5\%.

\section{HASIL DAN PEMBAHASAN}

\section{Tinggi Tanaman}

Terdapat interaksi dari perlakuan aplikasi PGPR dan dosis vermikompos pada variabel tinggi tanaman pada umur pengamatan 4, 5, 6 dan 7 bulan setelah tanam (BST). Hal ini menunjukkan bahwa pemberian PGPR mampu menurunkan kebutuhan vermikompos serta meningkatkan nilai tinggi tanaman tanaman tebu. Vermikompos mengandung sebagian besar nutrisi yang tersedia bagi tanaman seperti nitrat, fosfat, dan kalium (Kumar et al., 2018). Bahan organik sangat dibutuhkan 
mikroorganisme yang berperan sebagai sumber energi dalam menjalankan fungsi metabolismenya. Kinerja PGPR mendorong pertumbuhan tanaman dengan memproduksi IAA yang mampu merangsang pertumbuhan akar tanaman sehingga dapat meningkatkan luas bidang serapan hara tanaman. Bahan organik yang diaplikasikan pada tanah memiliki fungsi sebagai sumber karbon bagi mikroba tanah. Karbon tersebut yang dimanfaatkan oleh mikroba tanah untuk melaksanakan aktivitasnya (Deng et al., 2017). Nilai rerata tinggi tanaman pada perlakuan PGPR dan vermikompos terdapat pada Tabel 1.

Tabel 1. Rerata tinggi tanaman akibat interaksi antara vermikompos dan PGPR pada umur pengamatan 4, 5, 6 dan 7 BST

\begin{tabular}{|c|c|c|c|}
\hline \multirow{2}{*}{ Aplikasi PGPR } & \multicolumn{3}{|c|}{ Dosis vermikompos (t.ha $\left.{ }^{-1}\right)$} \\
\hline & 3,5 & 7 & 10,5 \\
\hline & -- & --- cm ----- & ------ \\
\hline \multicolumn{4}{|l|}{ Umur 4 BST } \\
\hline Tanpa PGPR & $106,3 \mathrm{a}$ & $112,6 \mathrm{a}$ & $137,2 \mathrm{~b}$ \\
\hline PGPR & $139,4 \mathrm{~b}$ & $159,0 \mathrm{c}$ & $142,2 \mathrm{bc}$ \\
\hline BNJ $5 \%$ & & 19,42 & \\
\hline KK $(\%)$ & & 9,57 & \\
\hline \multicolumn{4}{|l|}{ Umur 5 BST } \\
\hline Tanpa PGPR & $168,3 \mathrm{a}$ & $171,9 \mathrm{a}$ & $215,5 \mathrm{bc}$ \\
\hline PGPR & $203,1 \mathrm{bc}$ & $219,5 \mathrm{c}$ & $216,2 \mathrm{bc}$ \\
\hline BNJ 5\% & & 15,46 & \\
\hline $\mathrm{KK}(\%)$ & & 8,85 & \\
\hline \multicolumn{4}{|l|}{ Umur 6 BST } \\
\hline Tanpa PGPR & $210,5 \mathrm{a}$ & $259,4 \mathrm{~b}$ & $270,5 \mathrm{bc}$ \\
\hline PGPR & $266,8 \mathrm{bc}$ & $278,6 \mathrm{c}$ & $272,0 \mathrm{bc}$ \\
\hline BNJ 5\% & & 18,72 & \\
\hline $\mathrm{KK}(\%)$ & & 7,77 & \\
\hline \multicolumn{4}{|l|}{ Umur 7 BST } \\
\hline Tanpa PGPR & $241,1 \mathrm{a}$ & $264,3 \mathrm{ab}$ & $294,0 \mathrm{c}$ \\
\hline PGPR & $283,5 \mathrm{bc}$ & $302,3 \mathrm{c}$ & $290,1 \mathrm{bc}$ \\
\hline BNJ 5\% & & 28,81 & \\
\hline $\mathrm{KK}(\%)$ & & 6,65 & \\
\hline
\end{tabular}

Keterangan: Bilangan yang didampingi huruf yang sama menunjukkan bahwa tidak berbeda nyata berdasarkan uji beda nyata jujur $(\mathrm{BNJ}) 5 \%, \mathrm{BST}=$ bulan setelah tanam, $\mathrm{KK}=$ koefisien keragaman.

\section{Jumlah Anakan}

Tidak terjadi interaksi terhadap variabel jumlah anakan akibat perlakuan dari aplikasi PGPR serta dosis vermikompos pada umur pengamatan 2 sampai 6 BST. Hal ini dapat disimpulkan bahwa PGPR dapat mempengaruhi jumlah anakan tanaman tebu. Pada umur 12 bulan, varietas Bululawang mampu meningkatkan nilai jumlah anakan hingga 7 anakan (Rokhman, 2016). Keragaman bakteri pada PGPR memiliki berbagai macam fungsi diantaranya produksi asam indole-3-asetat (IAA), giberelin, pelarut fosfat serta kemampuan dalam mengikat nitrogen didalam tanah (Upadhyay et al., 2009). Hormon pertumbuhan seperti halnya ZPT pada PGPR merupakan senyawa penting dalam pertumbuhan tanaman, mulai dari pertumbuhan perakaran hingga pembentukan bunga dan buah pada tanaman. Nilai rerata jumlah anakan pada perlakuan PGPR dan vermikompos disajikan pada Tabel 2. 
Tabel 2. Rerata jumlah anakan pada perlakuan vermikompos dan PGPR pada umur pengamatan 2 sampai 6 BST

\begin{tabular}{|c|c|c|c|c|c|}
\hline \multirow{2}{*}{ Perlakuan } & \multicolumn{5}{|c|}{ Umur pengamatan (BST) } \\
\hline & 2 & 3 & 4 & 5 & 6 \\
\hline & ------- & - & nakan.r & -1 & - \\
\hline \multicolumn{6}{|l|}{ Aplikasi PGPR } \\
\hline Tanpa PGPR & $2,33 \mathrm{a}$ & $2,95 \mathrm{a}$ & $4,08 \mathrm{a}$ & $4,55 \mathrm{a}$ & $4,60 \mathrm{a}$ \\
\hline PGPR & $2,69 \mathrm{~b}$ & $3,55 \mathrm{~b}$ & $4,93 \mathrm{~b}$ & $5,04 \mathrm{~b}$ & $5,10 \mathrm{~b}$ \\
\hline BNJ 5\% & 0,33 & 0,44 & 0,41 & 0,46 & 0,48 \\
\hline $\mathrm{KK}(\%)$ & 15,33 & 15,42 & 10,39 & 10,98 & 11,36 \\
\hline \multicolumn{6}{|c|}{ Dosis Vermikompos $\left(\mathrm{t} \mathrm{ha}^{-1}\right)$} \\
\hline 3,5 & 2,46 & 3,04 & 4,29 & 4,40 & 4,46 \\
\hline 7 & 2,53 & 3,58 & 4,57 & 5,03 & 5,07 \\
\hline 10,5 & 2,54 & 3,13 & 4,65 & 4,94 & 5,03 \\
\hline BNJ 5\% & tn & tn & tn & tn & tn \\
\hline $\mathrm{KK}(\%)$ & 15,33 & 15,42 & 10,39 & 10,98 & 11,36 \\
\hline
\end{tabular}

Keterangan: Bilangan yang didampingi huruf yang sama pada kolom sama, menunjukkan tidak berbeda nyata berdasarkan uji beda nyata jujur $(\mathrm{BNJ}) 5 \%$, BST= bulan setelah tanam, $\mathrm{KK}=$ koefisien keragaman, $\mathrm{tn}=$ tidak nyata.

\section{Jumlah Batang}

Berdasarkan hasil dari penelitian didapatkan bahwa pada variabel jumlah batang menunjukkan tidak adanya interaksi antar perlakuan PGPR dan vermikompos. Namun, hasil analisis ragam menunjukkan perlakuan PGPR memberikan pengaruh nyata pada variabel jumlah batang pada umur 3 hingga 7 BST dan vermikompos pada umur 4 hingga 7 BST. Hal ini dapat disimpulkan bahwa PGPR dapat mempengaruhi jumlah batang tanaman tebu. Semakin tingginya jumlah batang mampu meningkatkan hasil tebu dimana jumlah batang dan bobot batang merupakan salah satu komponen dalam taksasi hasil tebu per hektar. Produk utama fotosintesis tebu adalah batang yang terbentuk dari pertumbuhan tunas. Produksi anakan mampu menentukan jumlah batang terpanen (Kadarwati, 2015). Nilai rerata jumlah batang pada perlakuan PGPR dan vermikompos disajikan pada Tabel 3.

Tabel 3. Rerata jumlah batang pada perlakuan vermikompos dan PGPR pada umur pengamatan 2 sampai 7 BST

\begin{tabular}{|c|c|c|c|c|c|c|}
\hline \multirow{2}{*}{ Perlakuan } & \multicolumn{6}{|c|}{ Umur pengamatan (BST) } \\
\hline & 2 & 3 & 4 & 5 & 6 & 7 \\
\hline & ---- & ----- & --------- & ng.rump & ------- & ------ \\
\hline \multicolumn{7}{|l|}{ Aplikasi PGPR } \\
\hline Tanpa PGPR & 3,23 & $3,87 \mathrm{a}$ & $4,91 \mathrm{a}$ & $5,18 \mathrm{a}$ & $5,38 \mathrm{a}$ & $5,55 \mathrm{a}$ \\
\hline PGPR & 3,74 & $4,52 \mathrm{~b}$ & $5,93 \mathrm{~b}$ & $6,04 \mathrm{~b}$ & $6,27 \mathrm{~b}$ & $6,38 \mathrm{~b}$ \\
\hline BNJ 5\% & tn & 0,37 & 0,39 & 0,37 & 0,37 & 0,42 \\
\hline $\mathrm{KK}(\%)$ & 19,47 & 10,24 & 8,24 & 7,55 & 7,31 & 8,19 \\
\hline \multicolumn{7}{|c|}{ Dosis Vermikompos $\left(\mathrm{t} \mathrm{ha}^{-1}\right)$} \\
\hline 3,5 & 3,28 & 3,90 & $4,90 \mathrm{a}$ & $5,11 \mathrm{a}$ & 5,26 a & $5,43 \mathrm{a}$ \\
\hline 7 & 3,60 & 4,42 & $5,68 \mathrm{~b}$ & $5,83 \mathrm{~b}$ & $6,07 \mathrm{~b}$ & $6,21 \mathrm{~b}$ \\
\hline 10,5 & 3,58 & 4,26 & $5,67 \mathrm{~b}$ & $5,88 \mathrm{~b}$ & $6,14 b$ & $6,25 \mathrm{~b}$ \\
\hline BNJ 5\% & tn & tn & 0,58 & 0,55 & 0,55 & 0,63 \\
\hline $\mathrm{KK}(\%)$ & 19,47 & 10,24 & 8,24 & 7,55 & 7,31 & 8,19 \\
\hline
\end{tabular}

Keterangan: Bilangan yang didampingi huruf yang sama pada kolom sama, menunjukkan tidak berbeda nyata berdasarkan uji beda nyata jujur (BNJ) $5 \%, \mathrm{BST}=$ bulan setelah tanam, KK= koefisien keragaman, tn: tidak nyata. 


\section{Jumlah Ruas}

Hasil pengamatan diketahui bahwa terdapat interaksi pada variabel jumlah ruas umur pengamatan 4 hingga 6 BST. Hal ini menunjukkan bahwa pemberian PGPR mampu menurunkan kebutuhan vermikompos serta meningkatkan nilai jumlah ruas tanaman tebu. Jumlah ruas memiliki hubungan yang positif dan menunjukkan pengaruh yang penting terhadap meningkatnya hasil tebu (Tena et al., 2016). Bahan organik yang terkandung didalam vermikompos terkandung beberapa enzim seperti lipase, amilase, kitinase dan selulase yang memiliki peran dalam memecah bahan organik didalam tanah yang membantu dalam melepaskan hara sehingga menjadi tersedia bagi tanaman. Nilai rerata jumlah ruas pada perlakuan PGPR dan vermikompos disajikan pada Tabel 4.

Tabel 4. Rerata jumlah ruas akibat interaksi antara vermikompos dan PGPR pada umur pengamatan 4,5 dan 6 BST

\begin{tabular}{|c|c|c|c|}
\hline \multirow{2}{*}{ Aplikasi PGPR } & \multicolumn{3}{|c|}{ Dosis vermikompos (t.ha-1) } \\
\hline & 3,5 & 7 & 10,5 \\
\hline & $\begin{array}{l}------ \\
--1\end{array}$ & ruas.batar & -- \\
\hline \multicolumn{4}{|l|}{ Umur 4 BST } \\
\hline Tanpa PGPR & $6,64 \mathrm{a}$ & $6,69 \mathrm{a}$ & $7,44 \mathrm{ab}$ \\
\hline PGPR & 6,86 a & $8,61 \mathrm{c}$ & $7,97 \mathrm{bc}$ \\
\hline BNJ 5\% & & 0,91 & \\
\hline KK (\%) & & 9,01 & \\
\hline \multicolumn{4}{|l|}{ Umur 5 BST } \\
\hline Tanpa PGPR & $8,72 \mathrm{a}$ & $8,89 \mathrm{ab}$ & $10,75 \mathrm{bc}$ \\
\hline PGPR & $8,92 \mathrm{ab}$ & $11,86 \mathrm{c}$ & $11,58 \mathrm{c}$ \\
\hline BNJ 5\% & & 2,01 & \\
\hline KK (\%) & & 7,62 & \\
\hline \multicolumn{4}{|l|}{ Umur 6 BST } \\
\hline Tanpa PGPR & $10,28 \mathrm{a}$ & $12,14 \mathrm{ab}$ & $12,97 \mathrm{~b}$ \\
\hline PGPR & $13,19 \mathrm{~b}$ & $13,31 \mathrm{~b}$ & $13,14 \mathrm{~b}$ \\
\hline BNJ 5\% & & 2,35 & \\
\hline KK (\%) & & 8,18 & \\
\hline
\end{tabular}

\section{Diameter Batang}

Terdapat interaksi antara perlakuan PGPR dan vermikompos pada variabel diameter batang pada umur pengamatan 5 dan 6 BST (bulan setelah tanam). Unsur hara merupakan faktor penting didalam besar kecilnya diameter batang tebu. Pada hasil pengamatan diketahui bahwa terdapat interaksi pada variabel diameter batang umur pengamatan 5 dan 6 BST. Hal ini menunjukkan bahwa pemberian PGPR mampu menurunkan kebutuhan vermikompos serta meningkatkan nilai diameter batang tanaman tebu. Hasil tebu berkorelasi positif dengan diameter tebu, jumlah anakan dan brix (Singh et al., 2013). Diameter batang dapat mencapai maksimal apabila lingkungan tumbuh tebu optimal. Nilai rerata diameter batang pada perlakuan PGPR dan vermikompos disajikan dalam Tabel 5. 
Tabel 5. Rerata diameter batang akibat interaksi antara vermikompos dan PGPR pada umur pengamatan 5 dan 6 BST

\begin{tabular}{|c|c|c|c|}
\hline \multirow{2}{*}{ Aplikasi PGPR } & \multicolumn{3}{|c|}{ Dosis vermikompos $\left(\right.$ t.ha $\left.^{-1}\right)$} \\
\hline & 3,5 & 7 & 10,5 \\
\hline \multirow{2}{*}{\multicolumn{4}{|c|}{ Umur 5 BST }} \\
\hline & & & \\
\hline Tanpa PGPR & $2,34 \mathrm{a}$ & $2,48 \mathrm{ab}$ & $2,82 \mathrm{bc}$ \\
\hline PGPR & $2,75 \mathrm{abc}$ & $2,98 \mathrm{c}$ & $2,80 \mathrm{abc}$ \\
\hline BNJ 5\% & & 0,47 & \\
\hline $\mathrm{KK}(\%)$ & & 7,53 & \\
\hline \multicolumn{4}{|l|}{ Umur 6 BST } \\
\hline Tanpa PGPR & $2,55 \mathrm{a}$ & $2,78 \mathrm{ab}$ & $3,07 \mathrm{c}$ \\
\hline PGPR & $2,88 \mathrm{bc}$ & $3,09 \mathrm{c}$ & $2,83 \mathrm{bc}$ \\
\hline BNJ 5\% & & 0,27 & \\
\hline $\mathrm{KK}(\%)$ & & 8,09 & \\
\hline
\end{tabular}

Keterangan: Bilangan yang didampingi huruf yang sama menunjukkan tidak berbeda nyata berdasarkan uji beda nyata jujur (BNJ) 5\%, BST= bulan setelah tanam, KK= koefisien keragaman.

\section{Nilai Brix}

Berdasarkan hasil penelitian didapatkan bahwa terdapat interaksi pada variabel nilai brix pada umur pengamatan 7 BST. Dapat ditarik kesimpulan bahwa pemberian PGPR mampu menurunkan kebutuhan vermikompos serta meningkatkan nilai brix tanaman tebu. Pada tanaman tebu, sukrosa disintesis yang bersumber dari daun tanaman tebu. Akumulasi sukrosa pada batang tebu dipengaruhi oleh suplai sukrosa yang akan memberikan dampak pada produktivitas tanaman (Wang et al., 2017). Nilai brix yang terkandung didalam batang tebu ini juga didukung dari perlakuan vermikompos yang mengandung sebagian besar nutrisi yang tersedia seperti nitrat, fosfat, kalium. Selain itu, bahan organik yang terkandung didalam vermikompos mampu dimanfaatkan mikroorganisme sebagai sumber nutrisi yang ditunjukkan dengan meningkatnya jumlah bakteri, aktinomiset dan jamur didalam tanah (Moradi et al., 2014). Nilai rerata nilai brix pada perlakuan PGPR dan vermikompos disajikan dalam Tabel 6.

Tabel 6. Rerata nilai brix akibat interaksi antara vermikompos dan PGPR pada umur pengamatan 7 BST

\begin{tabular}{|c|c|c|c|}
\hline \multirow{2}{*}{ Aplikasi PGPR } & \multicolumn{3}{|c|}{ Dosis vermikompos (t.ha $\left.{ }^{-1}\right)$} \\
\hline & 3,5 & 7 & 10,5 \\
\hline & \multicolumn{3}{|c|}{ 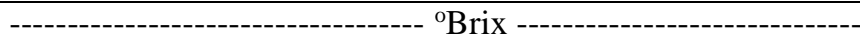 } \\
\hline Tanpa PGPR & $15,33 \mathrm{a}$ & $17,31 \mathrm{~b}$ & $18,67 \mathrm{bc}$ \\
\hline PGPR & $18,83 \mathrm{c}$ & $18,97 \mathrm{c}$ & $18,92 \mathrm{c}$ \\
\hline BNJ 5\% & \multicolumn{3}{|c|}{1,50} \\
\hline $\mathrm{KK}(\%)$ & \multicolumn{3}{|c|}{6,56} \\
\hline
\end{tabular}

Keterangan: Bilangan yang didampingi huruf yang sama menunjukkan tidak berbeda nyata, berdasarkan uji beda nyata jujur (BNJ) 5\%, BST: bulan setelah tanam, KK: koefisien keragaman.

\section{Taksasi Hasil}

Berdasarkan hasil penelitian didapatkan bahwa terdapat interaksi terhadap variabel taksasi hasil pada umur pengamatan 7 BST. Dapat disimpulkan bahwa pemberian PGPR mampu menurunkan kebutuhan vermikompos serta meningkatkan nilai taksasi tanaman tebu. Peningkatan dan perbedaan hasil tebu dapat disebabkan oleh pemupukan, distribusi air yang baik sepanjang siklus pertumbuhan tebu, pengelolaan tanaman, iklim dan varietas berbeda (Souza Bastos et al., 2015). Selain itu, peningkatan hasil tebu melalui faktor lingkungan dapat 
didukung oleh kesuburan dan ketersediaan bahan organik dalam tanah. Aplikasi bahan organik dapat meningkatkan penyerapan unsur $\mathrm{N}, \mathrm{P}$ dan $\mathrm{K}$ pada jaringan tanaman, baik itu tanaman plant cane (PC) maupun ratoon cane (RC). Bahan organik juga diperlukan sebagai sumber energi bagi bakteri. Bakteri didalam PGPR aktif mengkoloni akar-akar tanaman dan memiliki tiga peran utama diantaranya sebagai biofertilizer, biostimulant serta bioprotectant (Ningrum, 2014). Nilai rerata taksasi hasil pada perlakuan PGPR dan vermikompos disajikan pada Tabel 7.

Tabel 7. Rerata taksasi hasil akibat interaksi antara vermikompos dan PGPR pada umur pengamatan 7 BST

\begin{tabular}{cccc}
\hline \multirow{2}{*}{ Aplikasi PGPR } & \multicolumn{3}{c}{ Dosis vermikompos (t.ha ${ }^{-1}$ ) } \\
\cline { 2 - 4 } & 3,5 & 7 & 10,5 \\
\hline Tanpa PGPR & --------------------- t.ha $^{-1}$ & $66,53 \mathrm{~b}$ & $68,61 \mathrm{bc}$ \\
PGPR & $48,80 \mathrm{a}$ & $78,46 \mathrm{c}$ & $75,57 \mathrm{bc}$ \\
\hline BNJ 5\% & $69,49 \mathrm{bc}$ & \multicolumn{3}{c}{11,62} \\
\hline KK $(\%)$ & \multicolumn{3}{c}{7,46} \\
\hline
\end{tabular}

Keterangan: Bilangan yang didampingi huruf yang sama pada kolom sama menunjukkan tidak berbeda nyata, berdasarkan uji beda nyata jujur (BNJ) 5\%, BST: bulan setelah tanam, KK: koefisien keragaman, tn: tidak nyata.

\section{KESIMPULAN DAN SARAN}

\section{Kesimpulan}

PGPR dan vermikompos menunjukkan adanya interaksi yang ditunjukkan pada variabel tinggi tanaman, jumlah ruas, diameter batang, nilai brix dan taksasi hasil tanaman tebu. Pada nilai taksasi hasil umur 7 BST, perlakuan aplikasi PGPR pada dosis vermikompos 7 t.ha ${ }^{-1}\left(78,46\right.$ t.ha $\left.^{-1}\right)$ mampu menurunkan kebutuhan dosis vermikompos yang ditunjukan dengan nilai taksasi hasil yang lebih tinggi jika dibandingkan dengan tanpa aplikasi PGPR pada dosis vermikompos 3,5 t.ha- ${ }^{-1}$ dan dosis vermikompos 7 t.ha $^{-1}$. Bobot batang lebih tinggi didapatkan pada perlakuan PGPR (7,74 kg.rumpun ${ }^{-1}$ ) apabila dibandingkan pada perlakuan tanpa PGPR. Pada dosis vermikompos 7 t.ha $^{-1}$ $\left(7,36\right.$ kg.rumpun $\left.{ }^{-1}\right)$ dan dosis vermikompos 10,5 t.ha ${ }^{-1}\left(7,68\right.$ kg.rumpun $\left.{ }^{-1}\right)$ menunjukkan nilai bobot batang lebih tinggi jika dibandingkan dengan perlakuan vermikompos 3,5 t.ha ${ }^{-1}$ pada umur pengamatan 7 BST.

\section{Saran}

Dibutuhkan penelitian lebih lanjut mengenai dosis vermikompos yang berbeda dengan bahan dasar pupuk yang berbeda untuk mengetahui kualitas vermikompos lainnya. Serta dibutuhkan penelitian aplikasi PGPR pada fase tanaman tebu yang berbeda seperti pembibitan dengan varietas tebu yang berbeda. Saran diberikan sebagai tindak lanjut dan untuk bahan pengembangan penelitian berikutnya.

\section{UCAPAN TERIMA KASIH}

Ucapan terima kasih penulis sampaikan kepada Puslit Sukosari PTPN XI Lumajang, Jawa Timur yang telah mendukung dalam terlaksananya penelitian ini. 


\section{DAFTAR PUSTAKA}

Bhattacharyya, C., Banerjee, S., Acharya, U., Mitra, A., Mallick, I., Haldar, A., Haldar, S., Ghosh, A., \& Ghosh, A. (2020). Evaluation of Plant Growth Promotion Properties and Induction of Antioxidative Defense Mechanism by Tea Rhizobacteria of Darjeeling, India. Scientific Reports, 10(1): 15536.

Deng, X., Wu, C., Li, Q., \& Li, W. (2017). Effect of Vermicompost on Soil Enzyme Activity of Coastal Saline Soil in Water Spinach Plantation. Proceedings of the 2017 6th International Conference on Energy, Environment and Sustainable Development (ICEESD 2017). 2017 6th International Conference on Energy, Environment and Sustainable Development (ICEESD 2017), Zhuhai, China. Advances in Engineering Research, 129: 419-422.

Kadarwati. (2015). Peningkatan Produksi dan Rendemen Tebu (Sacharrum officinarum) Melalui Rawat Ratoon. Jurnal Littri, 21(4): 199-205.

Kumar, A., Prakash, C. H. B., Brar, N. S., \& Kumar, B. (2018). Potential of Vermicompost for Sustainable Crop Production and Soil Health Improvement in Different Cropping Systems. International Journal of Current Microbiology and Applied Sciences, 7(10): 1042-1055.

Moradi, H., Fahramand, M., Sobhkhizi, A., Adibian, M., \& Noori, M. (2014). Effect of Vermicompost on Plant Growth and Its Relationship with Soil Properties. International Jurnal of Farming and Allied Science, 3(3): 333-338.

Ningrum. (2014). Efikasi Herbisida Ametrin untuk Mengendalikan Gulma pada Pertanaman Tebu (Saccharum officinarum L.) Lahan Kering. Jurnal Agrotek Tropika, 2(2): 264-269.

Nisaa, A. K., Guritno. B., \& Sumarni, T. (2016). Pengaruh Pupuk Hijau Crotalaria mucronata dan C. juncea pada Pertumbuhan dan Hasil Tanaman Kedelai (Glycine max L. Merril). Jurnal Produksi Tanaman, 4(8): 602-610.

Rokhman. (2016). Jumlah Anakan dan Rendemen Enam Klon Tebu (Saccharum officinarum L.) Asal Bibit Bagal, Mata Ruas Tunggal dan Mata Tunas Tunggal. Vegalitika, 3(3): 89-96.

Setiawati, M. R., Sofyan, E. T., Nurbaity, A., Suryatmana, P., \& Marihot, G. P. (2018). Pengaruh Aplikasi Pupuk Hayati, Vermikompos dan Pupuk Anorganik Terhadap Kandungan N, Populasi Azotobacter sp. dan Hasil Kedelai Edamame (Glycine max (L.) Merill) pada Inceptisols Jatinangor. Agrologia, 6(1): 1-10.

Singh, S. P., Nigam, A., \& Singh, R. K. (2013). Influence of Rind Hardness on Sugarcane Quality. American Journal of Plant Sciences, 4(8): 45-52.

Souza Bastos, A. V., de Oliveira, R. C., da Silva, N. F., Teixeira, M. B., Loureiro Soares, F. A., \& da Silva, E. C. (2015). Productivity and Dry Matter Accumulation of Sugarcane Crop under Irrigation and Nitrogen Application at Rio Verde GO, Brazil. American Journal of Plant Sciences, 6(14): 2374-2384.

Stamford, N. P., Neto, D. E., de Freitas, A. D. S., Oliveira, E. C. A., Oliveira, W. S., \& Cruz, L. (2015). Rock Biofertilizer and Eartheworm Compost on Sugarcane Performance and Soil Attributes in Two Consecutive Years. Scientia Agricola, 73 (1): 29-33.

Tando, E. (2017). Review: Peningkatan Produktivitas Tebu (Saccarum Officinarum 1.) pada Lahan Kering Melalui Pemanfaatan Bahan Organik dan Bahan Pelembab Tanah Sintesis. Biotropika Journal of Tropical Biology, 5(3): 90-96. 
Tena, E., Mekbib, F., \& Ayana, A. (2016). Heritability and Correlation among Sugarcane Yield and Some Agronomic and Sugar Quality Traits in Ethiopia. American Journal of Plant Sciences, 7(10): 1453-1477.

Upadhyay, S. K., Singh, D. P., \& Saikia, R. (2009). Genetic Diversity of Plant Growth Promoting Rhizobacteria Isolated from Rhizospheric Soil of Wheat Under Saline Condition. Current Microbiology, 59(5): 489-496.

Wang, J., Zhao, T., Yang, B., \& Zhang, S. (2017). Sucrose Metabolism and Regulation in Sugarcane. Journal of Plant Physiology \& Pathology, 5(4).

Zhang, Y., Sun, C., Chen, Z., Zhang, G., Chen, L., \& Wu, Z. (2019). Stoichiometric analyses of soil nutrients and enzymes in a Cambisol soil treated with inorganic fertilizers or manures for 26 years. Geoderma, 353: 382-390. 